\title{
Evaluation of Adenanthera pavonina Bark Extracts for Antioxidant Activity and Cytotoxicity against Cancer Cell Lines
}

\author{
Renilda Sophy A. J. ${ }^{1}$, Albin T. Fleming ${ }^{2}$ \\ ${ }^{1}$ PG \& Research Department of Advanced Zoology and Biotechnology, Loyola College, Chennai, India -600034 \\ ${ }^{2}$ Associate Professor, PG \& Research Department of Advanced Zoology and Biotechnology, Loyola College, Chennai, India-600034
}

\begin{abstract}
Plant materials were used for the treatment of malignant diseases for centuries. Various studies on plant extract which have a suitable history of use in folklore for the treatment of cancer had often resulted in the isolation of principles with anti-tumour activity. In the present study, the anti-proliferative effect of acetone and methanol bark extracts of Adenanthera pavonina on three cancer cell lines using sulforhodamine-B assay and their antioxidant activities using 1-diphenyl-2-picrylhydazyl radical and its reducing ability were investigated. NCI-H460, U251, and MCF7 cancer cell lines were used in this assay. The GI50 value of methanol extract showed a lowest value of $27 \mu \mathrm{g} / \mathrm{mL}$ against $\mathrm{NCI}-\mathrm{H} 460$. The antioxidant and the reducing power assay showed a significant dose dependant activity. The study also suggests that antioxidant activity of these extracts might be one of the reasons for the anticancer potential of the extracts.
\end{abstract}

Keywords: Extracts, anti-tumor, cell lines, antioxidant, cytotoxicity

\section{Introduction}

It is being realized that that there is an increase in the incidence of cancer worldwide in spite of cancer awareness, life style modification and new drugs. Bioactive principles were sought in the very early part of the nineteenth century, during which investigation of well known medicinal plants lead to the discovery of a number of biologically active alkaloids. Some of them like morphine, atropine, papavarine and codeine became cornerstones of many aspects of drug discovery. Majority of the cancer drugs originated from natural products like Taxol, Vincristine and Camptothecin which saw the light by traditional in vitro cell based cytotoxic assays before their real molecular biological targets were identified. Today, with the advent of genomic research and new molecular biology tools for developing bioassays, more sophisticated biological assays in addition to cell-based assays are being employed routinely in the drug discovery paradigm. As a result, a large number of plant derived drugs continue to be discovered on the basis of traditional knowledge like ayurveda, siddha etc.

Oxidative stress is an important contributor to the pathophysiology of a variety of conditions including carcinogenesis, diabetes, cardiovascular dysfunctions, atherosclerosis, inflammation, drug toxicity, reperfusion injury and neurodegenerative diseases (Aruoma, 1998). Antioxidants are believed to play an important role in preventing or alleviating chronic diseases by reducing the oxidative damage to cellular components caused by reactive oxygen species (ROS) (Ceriello, 2003; Vinson, Dabbag, Serry, \& Jang, 1995). Numerous plant constituents have shown free radical scavenging or antioxidant activity (Sunil \& Ignacimuthu, 2011). There is a growing interest in natural phenolic antioxidants, present in medicinal and dietary plants, that might help attenuate oxidative damage (Rice-
Evans, Miller, \& Paganga, 1997; Silva, Ferreres, Malva, \& Dias, 2005).

Adenanthera pavonina is a tree commonly called as red sandalwood, also known as the coral-wood or Barbados' pride. It is largely populous in India, China, and in Costa Rica. The red sandalwood has been part of the alternative Ayurvedic medicine, as the tree is endemic in India. It is reported to have a rich amount of flavanoids (Rastogi and Mehrotraa, 1991) mainly gallic acid, terpenoids, tannis, sterols (beta-sitosterol, beta-sitosterol-3 $\beta$-D-glucoside), triterpinoids (nonacosane and hentriacontane) and saponins (sapogenins) (Hussain Arshad and Hussain Sarfaraj, 2010). These phytochemicals are known to have many biological activities. In vitro studies show that Adenanthera pavonina leaf extract has antibacterial activity against the intestinal pathogen Campylobacter jejuni (Dholvitayakhun et al., 2012). Also, high doses of seed extract have an antiinflammatory effect in studies in rats and mice (Olajide, et al., 2004). We have used acetone and methanol extracts of $A$. pavonina to evaluate the anticancer potential and to determine the antioxidative and free radical scavenging capabilities of the extract.

\section{Materials and Method}

Chemicals and reagents

DPPH (1,1-diphenyl,2-picrylhydrazyl), TCA (trichloro acetic acid), ferric chloride and BHT (butylated hydroxyl toluene) were obtained from Sigma chemical co., USA. Ascorbic acid was obtained from SD fine chem. Ltd., Biosar, India. All the other chemicals were of analytical grade.

\section{Collection}

Bark of Adenanthera pavonina were collected from the suburbs of Chennai, Tamil Nadu, India. The taxonomic 


\section{International Journal of Science and Research (IJSR) \\ ISSN (Online): 2319-7064 \\ Index Copernicus Value (2013): 6.14 | Impact Factor (2014): 5.611}

authentication was done by Dr. P. Jayaraman, Plant Anatomy Research Centre, Tambaram, Chennai. The voucher specimen number is PARC/2014/2022.

\section{Preparation of Crude Extracts}

The collected bark pieces were washed with running tap water, again washed with distilled water, air dried, homogenized to a fine powder and stored in air-tight bottles. Dried bark of $A$. pavonina was extracted with petroleum ether to remove wax using soxhlet extraction method. The bark powder was dried again and then extracted with acetone and methanol separately. The soxhlet was run until the solvent colour turned colourless. The extract was evaporated to dryness in a rotary vacuum evaporator. The extract was stored at $4^{\circ} \mathrm{C}$ in airtight sterile vials for further studies.

\section{DPPH Radical Scavenging Assay}

DPPH quenching ability of $A$. pavonina acetone and methanol extracts were measured according to Hanato, Kagawa,Yasuhara, and Okuda (1988). The methanol DPPH solution $(0.15 \%)$ was mixed with different concentrations $(200-1000 \mathrm{~g} / \mathrm{ml})$ of the extracts. After incubation for 30 min, the absorbance was read at $515 \mathrm{~nm}$. The antiradical activity was expressed as IC50 ( $/ \mathrm{ml}$ ), (the antiradical dose required to cause a $50 \%$ inhibition). Ascorbic acid was used as standard. The ability to scavenge the DPPH radical was calculated using the following equation:

DPPH scavenging effect $(\%)=\mathrm{A}_{0}-\mathrm{A}_{1} / \mathrm{A}_{0} \times 100$

where, $\mathrm{A}_{0}$ is the absorbance of the control at $30 \mathrm{~min}$, and $\mathrm{A}_{1}$ is the absorbance of the sample at $30 \mathrm{~min}$. All samples were analysed in triplicate.

\section{Reducing Ability Assay}

The reducing power of $A$. pavonina acetone and methanol extracts were evaluated according to the method of Oyaizu (1986). Different concentrations of the extracts in distilled water $(200-1000 \mathrm{~g} / \mathrm{ml})$ were mixed with $2.5 \mathrm{ml}$ of $0.2 \mathrm{M}$ phosphate buffer ( $\mathrm{pH} 6.6$ ), and $2.5 \mathrm{ml}$ of $1 \% \mathrm{~K}_{3} \mathrm{Fe}(\mathrm{CN})_{6}$. The mixture was incubated at $50^{\circ} \mathrm{C}$ for $20 \mathrm{~min}$. After incubation, $2.5 \mathrm{ml}$ of $10 \%$ TCA was added to the mixture and centrifuged at $3000 \mathrm{rpm}$ for $10 \mathrm{~min}$. The upper layer of the solution $(2.5 \mathrm{ml})$ was mixed with distilled water $(2.5 \mathrm{ml})$ and $\mathrm{FeCl}_{3}(0.5 \mathrm{ml}, 0.1 \%)$, and the absorbance was measured at $700 \mathrm{~nm}$. Increase in absorbance of the reaction mixture indicated the ability of reducing power. Butylated hydroxyl toluene (BHT) was used as standard.

\section{Antiproliferative Assay \\ The growth inhibitory activity of the acetone and methanol extracts of bark of Adenanthera pavonina were evaluated against cell line panel consisting of NCI-H460 (lung cancer), MCF7 (breast cancer) and U251 (brain cancer cell) using SRB assay. The cell lines were obtained from the American Type Culture Collection (ATCC). The cell lines were routinely maintained as monolayer cell cultures in Roswell Park Memorial Institute medium containing heat in-activated fetal bovine serum $(10 \%$, Gibco), and glutamine, penicillin and streptomycin solution (1\%, L-glutamine, penicillin and streptomycin). Briefly, $100 \mu \mathrm{L}$ of cell suspension were plated in each well of 96-well plates, and incubated for $24 \mathrm{~h}$ at 37}

${ }^{\circ} \mathrm{C}$ in a humidified $\mathrm{CO}_{2}(5 \%)$ incubator. The stock solutions of the two solvent extracts were prepared in dimethyl sulfoxide (DMSO) as a vehicle and various dilutions of the crude extracts $(1,0.5,0.25,0.125,0.0625,0.0312$, and $0.0156 \mathrm{mg} / \mathrm{ml})$ were added $(100 \mu \mathrm{l})$ in each well. After $48 \mathrm{~h}$ of incubation, cold $\left(4^{\circ} \mathrm{C}\right)$ trichloroacetic acid $(50 \%, 100 \mu \mathrm{l})$ was added gently and left for 1 hour at $4^{\circ} \mathrm{C}$, followed by washing with distilled water and air dried at room temperature. To each well, $100 \mu \mathrm{l}$ of SRB solution was added and kept in dark for 30 minutes; the unbound stain was washed off with acetic acid (1\%) and air-dried at room temperature. The protein bound stain was solubilised with $10 \mathrm{mM}$ tris-base $(\mathrm{pH} \mathrm{10.2)} \mathrm{with} \mathrm{shaking} \mathrm{for} 5 \mathrm{~min}$ followed by the measures of the absorbance at $515 \mathrm{~nm}$ using a microplate reader. Camptothecin was used as positive control. $\mathrm{GI}_{50}$ which is the concentration of the extract or camptothecin causing $50 \%$ growth inhibition of cells was determined.

\section{Results and Discussion}

\section{DPPH radical scavenging activity}

The DPPH radical is a stable organic free radical with an absorption maximum band around 515-528 nm and thus, it is a useful reagent for evaluation of antioxidant activity of compounds (Sanchez-Moreno, 2002). In the DPPH test, the antioxidants reduce the DPPH radical to a yellow-coloured compound, diphenylpicrylhydrazine, and the extent of the reaction will depend on the hydrogen donating ability of the antioxidants (Bondent, Brand-Williams, \& Bereset, 1997). It has been documented that cysteine, glutathione, ascorbic acid, tocopherol, polyhydroxy aromatic compounds (e.g., hydroquinone, pyrogallol, gallic acid), reduce and decolorize 1,1-diphenyl-2-picrylhydrazine by their hydrogen donating capabilities (Blois, 1958). The acetone and methanol extracts of $A$. pavonina exhibited a significant dose dependent inhibition of DPPH activity. Methanol exhibited a $50 \%$ inhibition (IC50) at a concentration of $400 \mu \mathrm{g} / \mathrm{mL}$. The results are presented in figure 1.

\section{Reducing power}

It has been reported that reducing power is associated with antioxidant activity and may serve as a significant reflection of the antioxidant activity (Oktay et al., 2003). Compounds with reducing power indicate that they are electron donors, and can reduce the oxidized intermediates of lipid peroxidation processes so that they can act as primary and secondary antioxidants (Yen and Chen, 1995). For the measurements of the reductive ability, we studied the Fe3+ to $\mathrm{Fe} 2+$ transformation in the presence of $A$. pavonina extracts. Figure 2 shows the reducing capabilities of acetone and methanol extracts of $A$. pavonina compared to butylated hydroxyl toluene. The plant extract could reduce $\mathrm{Fe} 3+$ ions, and the reducing power was comparatively lesser than the standard of butylated hydroxy toluene. The reducing power of methanol extract was very potent than acetone extract and the reducing power of the both extracts increased with quantity of sample.

\section{Volume 4 Issue 12, December 2015}




\section{International Journal of Science and Research (IJSR) \\ ISSN (Online): 2319-7064}

Index Copernicus Value (2013): 6.14 | Impact Factor (2014): 5.611

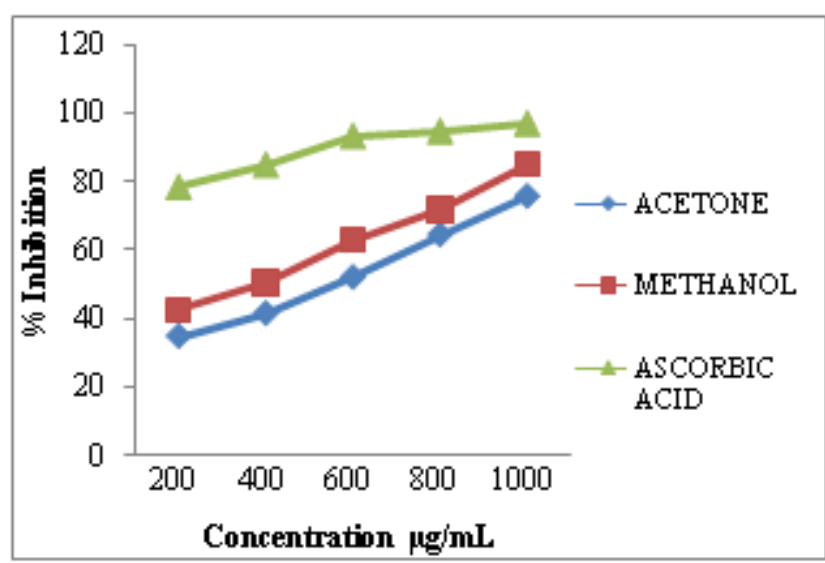

Figure 1: DPPH scavenging effect of different concentrations $(200-1000 \mu \mathrm{g} / \mathrm{ml})$ of

A. pavonina acetone and methanol extracts and ascorbic acid.

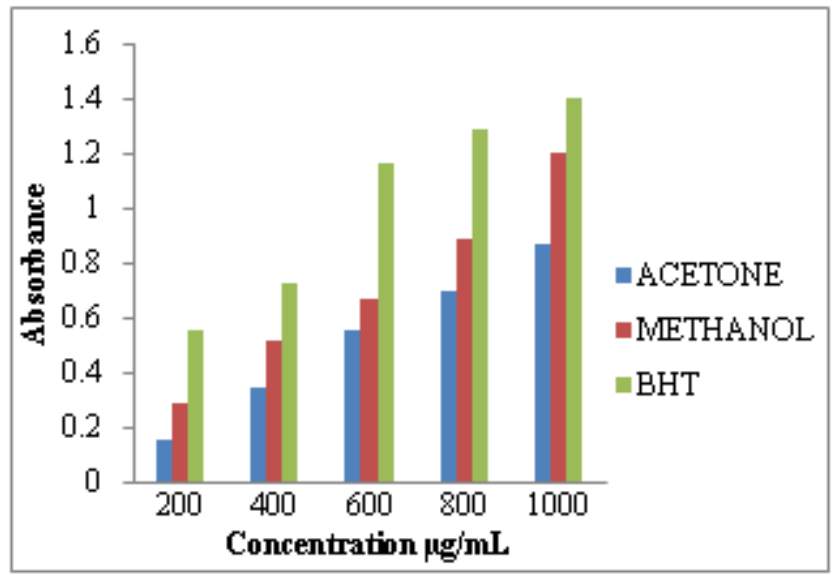

Figure 2: Reductive ability of different concentrations $(200-1000 \mu \mathrm{g} / \mathrm{ml})$ of acetone and methanol extracts of $A$. pavonina and BHT.

\section{Antiproliferative Activity}

The lower GI50 values of methanol extract reflected a higher antiproliferative activity. The acetone extracts showed a comparatively less antiproliferative activity than methanol extract (Figure 3). The GI50 value of methanol was lowest against NCI-H460 with a GI50 value of $27 \mu \mathrm{g} / \mathrm{mL}$. The acetone extract showed highest GI50 value of $130 \mu \mathrm{g} / \mathrm{mL}$ against U251. According to a previous study, the maximum growth inhibition shown by the crude extract of Caralluma tuberculata against MCF-7 cell line was $82 \%$ at a concentration of $500 \mu \mathrm{g} / \mathrm{mL}$ (Ahmed et al., 2009). Valko et al.,(2006) investigated the cytotoxicity effects of water extracts from leaves and branches of Philadelphus coronarius (Hydrangeaceae), against A431 cells (human skin carcinoma cell line) and the human breast adenocarcinoma cell line with various doses. Highest toxic effects were observed against MCF-7 cell line. The result of the present study is in accordance with the effect of crude methanol extract of the stem of Debregeasia salicifolia on the growth of MCF-7 cell line investigated by the MTT assay. D. salicifolia was also highly active against MCF-7 cell line. The maximum percentage inhibition value obtained for $D$. salicifolia was $99 \%$. Minimum percentage inhibition was observed at extract concentration of $10 \mu \mathrm{g} / \mathrm{mL}$ that was $37.9 \%$ (Nisa et al.,2011). The present study showed dose dependent response. Other related research also showed that antiproliferative activity or cytotoxicity were in a dosedependent manner (Yuan and Walsh, 2006). In accordance with the present study, the ethanol extract of peel and flesh of Coleus tuberosus showed both antioxidant and cytotoxic activity against cancer cell lines (Nugraheni et al., 2011). Moreover, the antioxidant rich sea weeds Dictyota dichotoma, Hormophysa triquerta, Spatoglossum asperum, Stoechospermum marginatum and Padina tetrastromatica comprehensively promoted anti pancreatic tumor potential, as evidently demonstrated by inhibitions of cell viability, proliferation and induced apoptotic cell death. With increasing concentrations of the algal polyphenol fractions, a dose dependent inhibition of cell viability in MiaPaCa-2 cells exposed to dichloromethane or ethyl acetate fractions was observed. (Aravindan et al.,2013).

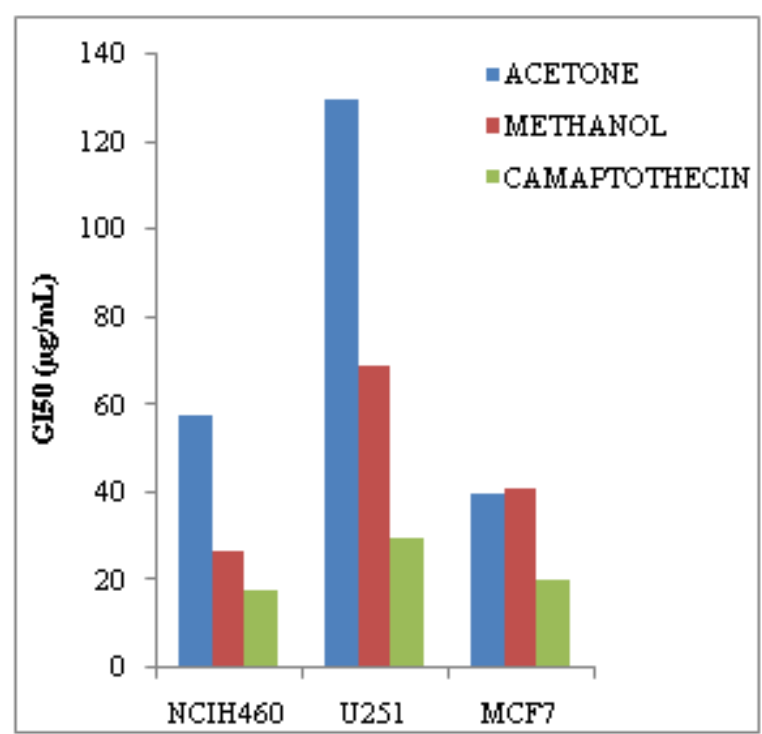

Figure 3: GI50 values of acetone, methanol extracts and camptothecin against different cell lines

\section{Conclusion}

This study, using in vitro assay systems suggested that $A$. pavonina extracts possessed anticancer potential. The antioxidant potential evaluated based on DPPH scavenging activity and the reducing power of the extracts confirmed the antioxidant and free radical scavenging activity of the extract. The antioxidant property of the extracts showed a correlation with the anticancer property of the extracts. This study suggests that the antioxidant activity of these extracts might be helpful in preventing or slowing the progress of oxidative stress-related diseases like cancer. Identification of the antioxidant constituents of the plant which are helpful for the anti-cancer properties are yet to be studied.

\section{References}

[1] Ahmed, S., Owen, C.P., Waheed, A., Nisa, S., Bibi, Y., and Chaudhary, M.F. (2009). Biochemical evaluation of extracts from Caralluma tuberculata against hormonedependent breast cancer cells. J. Pharm. Pharmacol.183 supplement Issue.

[2] Aravindan, S., Delma, C.R., Thirugnanasambandan, S.S., Herman, T.S., and Aravindan, N. (2013). Anti-

\section{Volume 4 Issue 12, December 2015}




\section{International Journal of Science and Research (IJSR) \\ ISSN (Online): 2319-7064}

Index Copernicus Value (2013): 6.14 | Impact Factor (2014): 5.611

Pancreatic Cancer Deliverables from Sea: First-Hand Evidence on the Efficacy, Molecular Targets and Mode of Action for Multifarious Polyphenols from Five Different Brown-Algae. PLoS ONE 8(4): e61977.

[3] Aruoma, O. I. (1998). Free radicals, oxidative stress and antioxidants in human health and disease. Journal of the American Oil Chemical Society, 75, 199-212.

[4] Ceriello, A. (2003). New insights on oxidative stress and diabetic complication may lead to a "causal" antioxidant therapy. Diabetes Care, 26, 1589-1596.

[5] Dholvitayakhun, A., Cushnie, T.P.T., and Trachoo, N. (2012). Antibacterial activity of three medicinal Thai plants against Campylobacter jejuni and other food borne pathogens. Natural Product Research 26 (4): 356363.

[6] Hanato, T., Kagawa, H., Yasuhara, T., and Okuda, T. (1988). Two new flavonoids and other constituents in licorice root: Their relative astringency and radical scavenging effects. Chemical \& Pharmaceutical Bulletin, 36, 2090-2097.

[7] Hussain Harshad, Hussain, M.Sarfaraj. (2010). Pharmacognostical Stardardization of Stem Bark of Adenanthera pavonina L. Phcog Net, 2(8).

[8] Nugraheni, M., Santoso, U., Suparmo and Wuryastuti, H., (2011). Potential of Coleus tuberosus as an antioxidant and cancer chemoprevention agent. International Food Research Journal 18(4): 1471-1480.

[9] Oktay, M., Gulcin, I., and Kufrevioglu, O. I. (2003). Determination of in vitro antioxidant activity of fennel (Foeniculum vulgare) seed extracts. LebensmittelWissenschaft Und Technoogie, 36, 263-271.

[10] Olajide, O.A., Echianu, C.A., Adedapo, A.D., and Makinde, J.M. (2004). Anti-inflammatory studies on Adenanthera pavonina seed extract. Inflammopharmacology 12(2): 196-202.

[11] Rice-Evans, C. A., Miller, N. J., and Paganga, G. (1997). Antioxidants properties of phenolic compounds. Trends in Plant Science, 2, 152-159.

[12] Silva, B. A., Ferreres, F., Malva, J. O., \& Dias, A. C. P. (2005). Phytochemical and antioxidant characterization of Hypericum perforatum alcoholic extracts. Food Chemistry, 90, 157-167.

[13] Sobia Nisa, Yamin Bibi, Abdul Waheed, Muhammad Zia, Sadia Sarwar, Sabbir Ahmed and M. Fayyaz Chaudhary (2011). Evaluation of anticancer activity of Debregeasia Salicifolia extract against estrogen receptor positive cell line. African Journal of Biotechnology Vol. 10(6), pp. 990-995.

[14] Sunil, C., and Ignacimuthu, S. (2011). In vitro and in vivo antioxidant activity of Symplocos cochinchinensis S. Moore leaves containing phenolic compounds. Food and Chemical Toxicology, 49, 1604-1609.

[15] Valko, V., Fickova, M., Pravdova, E., Nagy, M., Grancai, D., and Czigle, S. (2006). Cvtotoxicity of water extracts from leaves and branches of Philadelphus coronaries L. Biomed Pap Med Fac Univ Palacky Olomouc Czech Repub, 150 (1):71-73. 71.

[16] Vinson, J., Dabbag, Y. A., Serry, M. M., and Jang, J. (1995). Plant flavonoids, especially tea flavonols, are powerful antioxidants using an in vitro oxidation model for heart disease. Journal of Agricultural and Food Chemistry, 43, 2800-2802.
[17] Yen, G. C., and Chen, H. Y. (1995). Antioxidant activity of various tea extracts in relation to their antimutagenicity. Journal of Agricultural and Food Chemistry, 43, 27-32.

[18] Yuan Y.V., and Walsh, N.A. (2006). Antioxidant and antiproliferative activities of extracts from a variety of edible seaweeds. Food Chemistry and Toxicology, 44: 1144-1150.

\section{Author Profile}

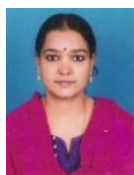

Renilda Sophy A. J. PG \& Research Department of Advanced Zoology and Biotechnology, Loyola College, Chennai, India-600034.

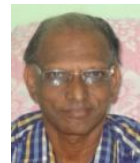

Albin T. Fleming, Associte Professor, PG \& Research Department of Advanced Zoology and Biotechnology, Loyola College, Chennai, India 600034 